\title{
Low water column nitrogen fixation in the Mediterranean Sea: basin-wide experimental evidence
}

\author{
Nona S. R. Agawin ${ }^{1, *}$, Antonio Tovar-Sanchez ${ }^{2}$, Lucas J. Stal ${ }^{3,4}$, Marta Alvarez ${ }^{2,5}$, \\ Susana Agustín ${ }^{2}$, Carlos M. Duarte ${ }^{2}$ \\ ${ }^{1}$ Interdisciplinary Ecology Group, Biology Department, Universidad de las Islas Baleares, 07122 Palma de Mallorca, Spain \\ ${ }^{2}$ Department of Global Change Research, IMEDEA (UIB-CSIC), Instituto Mediterraneo de Estudios Avanzados, \\ 07190 Esporles, Mallorca, Spain \\ ${ }^{3}$ Department of Marine Microbiology, Netherlands Institute of Ecology (NIOO KNAW), Yerseke, The Netherlands \\ ${ }^{4}$ Department of Aquatic Microbiology, Institute for Biodiversity and Ecosystem Dynamics, University of Amsterdam, \\ Amsterdam, The Netherlands \\ ${ }^{5}$ Present address: IEO, Centro de A Coruña, Apdo. 130, 15080, A Coruña, Spain
}

\begin{abstract}
The abundance and nitrogen fixation rates of Trichodesmium sp. integrated down to the deep chlorophyll maximum as well as nitrogen fixation rates in size-fractionated discrete surface water samples were measured across the Mediterranean Sea. The abundance of Trichodesmium sp. was generally low $\left(<50\right.$ trichomes $\left.\mathrm{m}^{-3}\right)$, except at one station in the Tyrrhenian Sea where the water temperature was $>20^{\circ} \mathrm{C}$ and Trichodesmium sp. was present at a higher density (ca. 700 trichomes $\left.\mathrm{m}^{-3}\right)$. Across the basin, size-fractionated nitrogen fixation rates were low $\left(<250 \mathrm{nmol} \mathrm{N} \mathrm{m}^{-3} \mathrm{~h}^{-1}\right)$. The highest rate was measured at a station characterized by relatively high concentrations of total dissolved $\mathrm{P}$ and dissolved Fe. High $\delta^{15} \mathrm{~N}$ values $(8.04 \pm 2.03 \%)$ of the particulate organic nitrogen were in accordance with the observed low water column nitrogen fixation rates across the Mediterranean Sea.
\end{abstract}

KEY WORDS: Nitrogen fixation · Trichodesmium sp. $\cdot$ Mediterranean Sea

\section{INTRODUCTION}

Water exchanges in the semi-enclosed Mediterranean Sea occur mainly through the Strait of Gibraltar. Across the Strait of Gibraltar, water circulation is intriguingly characterized by an unbalanced flow of N-depleted (organic and inorganic nitrogen) inflow of Atlantic surface water compared to the outflow of N-enriched deep Mediterranean waters (Béthoux \& Copin-Montégut 1986). The deep Mediterranean waters have an anomalous nitrogen to phosphorus (N:P) ratio increasing from 22 in the western basin to 24 to 29 in the east (Krom et al. 1991, Béthoux et al. 2002). These values are well above the Redfield molar ratio of 16 that is typical for the ocean. These high N:P ratios indicate that the Mediterranean Sea is enriched with $\mathrm{N}$ compared to $\mathrm{P}$ or, alternatively, that the system is highly deprived of $\mathrm{P}$, with P-limitation increasing from the west to the east (Moutin \& Raimbault 2001). Several sources of external combined $N$ have been identified in the Mediterranean Sea in order to explain these high N:P ratios. These sources include terrestrial discharges (natural and anthropogenic, UNEP/WMO 1997, Béthoux \& Copin-Montégut 1986), riverine discharge, atmospheric deposition (Kouvarakis et al. 2001, Sandroni et al. 2007, Markaki et al. 2008), and the biological fixation of atmospheric dinitrogen (Béthoux \& Copin-Montégut 1986, Garcia et al. 2006, Sandroni et al. 2007). Terrestrial discharges in the Mediterranean Sea have N:P ratios of $<8$. Whereas 
the Mediterranean P budget can be balanced by heavy terrestrial loads (Béthoux \& Copin-Montégut 1986), the $\mathrm{N}$ budget remains unbalanced when only terrestrial nutrient loads are taken into account. Atmospheric deposition of $\mathrm{N}$ and to a lesser extent $\mathrm{P}$ has recently been recognized as important sources of nutrients in the Mediterranean region (Markaki et al. 2008, Koçak et al. 2010). These atmospheric depositions possess high N:P ratios of up to 22, increasing from the western to the eastern basin (Markaki et al. 2003). Hence, atmospheric deposition represents an important source of nitrogen and provides a link to the high N:P ratio in the system (Markaki et al. 2008, Koçak et al. 2010). Atmospheric deposition of $\mathrm{N}$ can account up to $61 \%$ of the total $\mathrm{N}$ budget in the Eastern Mediterranean Sea (Krom et al. 2004). Ridame et al. (2003) suggested that the high N:P ratio in the Mediterranean Sea may be the result of a combination of the atmospheric deposition of $\mathrm{N}$ and the biological fixation of atmospheric dinitrogen. Based on nitrogen isotope ratio analysis of phytoplankton, suspended particles and nitrate along the Mediterranean basin in different seasons, Pantoja et al. (2002) estimated that biological $\mathrm{N}_{2}$ fixation may provide up to 20 and $90 \%$ of new nitrogen in the western and eastern basins, respectively. Actual biological $\mathrm{N}_{2}$ fixation rate measurements have only been published within the last $5 \mathrm{yr}$ (Garcia et al. 2006, Rees et al. 2006, Sandroni et al. 2007, Ibello et al. 2010, Bonnet et al. 2011, Yogev et al. 2011) with values ranging from very low $\left(<4 \mu \mathrm{mol} \mathrm{N} \mathrm{m}^{-2} \mathrm{~d}^{-1}\right.$, Ibello et al. 2010) to extremely high rates measured in a Cyprus eddy in one study (129 $\mathrm{\mu mol} \mathrm{N} \mathrm{m}{ }^{-3} \mathrm{~d}^{-1}$; Rees et al. 2006). Few of the studies (Ibello et al. 2010, Bonnet et al. 2011) have measured actual biological $\mathrm{N}_{2}$ fixation rates on a basinwide scale despite previous estimations of differences in the contribution of biological $\mathrm{N}_{2}$ fixation to new nitrogen in the western and eastern basins (Pantoja et al. 2002). Therefore more extensive measurements are needed in order to assess the importance of this process in the Mediterranean Sea on a basin-wide scale. In addition, studies on the occurrence and abundance of the globally important diazotrophic cyanobacterium Trichodesmium has not been done on a basin-wide scale in the Mediterranean Sea except for some rare reports of its presence (Margalef 1969, Le Moal \& Biegala 2009) and absence (Man-Aharonovich et al. 2007). Moreover, a limited number of studies dealt with the effect of physico-chemical factors on $\mathrm{N}_{2}$ fixation in the Mediterranean Sea. Temperature (Langlois et al. 2005), combined N (Fu \& Bell 2006), P (Sañudo-Wilhemy et al. 2001), trace metals such as Fe, Mo, V (Marino \& Howarth 1990, Berman-Frank et al. 2001, Tovar-Sánchez \& Sañudo-Wilhelmy 2011) and atmospheric dust as a source of Fe have all been attributed as factors that control $\mathrm{N}_{2}$ fixation in the sea.
Here, we have measured $\mathrm{N}_{2}$ fixation and the occurrence and abundance of the $\mathrm{N}_{2}$-fixing cyanobacterium Trichodesmium in the Mediterranean Sea and assessed their spatial variability. We have correlated these data with physico-chemical factors (temperature, inorganic nutrients and trace metal $[\mathrm{Fe}, \mathrm{V}$, Mo] availability). These investigations were carried out during 2 research cruises that took place during spring-summer of 2006 and 2007 (THRESHOLDS I and THRESHOLDS II, respectively) covering transects from the western to the eastern parts of the Mediterranean Sea.

\section{MATERIALS AND METHODS}

Study area and sampling. The study was carried out on board of the oceanographic vessel BIO García del Cid during 2 cruises to the Mediterranean Sea: (1) Cruise tHRESHOLDS I, from June 5 to June 30, 2006, (35.6 to $41.9^{\circ} \mathrm{N}, 3.6$ to $30.1^{\circ} \mathrm{E}$; Fig. 1), and (2) Cruise THRESHOLDS II, from May 4 to June 6, 2007 (31.5 to $39.35^{\circ} \mathrm{N}, 3.5$ to $29.5^{\circ} \mathrm{E}$; Fig. 1). The THRESHOLDS (thresholds of environmental sustainability) cruises were originally planned to evaluate the critical values of pressures (e.g. contaminants, inorganic, and organic nutrient inputs) beyond which an indicator (e.g. biodiversity, water, and sediment quality) shifts to a different state. Each of the cruises consisted of 2 legs, starting from Spanish waters (off Barcelona) to the Black Sea, and back. For the purpose of this paper, data were collected from both legs of THRESHOLDS I and from one leg (east to west transect) of THRESHOLDS II.

At each station during THRESHOLDS I and II, temperature, salinity, and fluorescence were recorded down to $200 \mathrm{~m}$ depth using a SeaBird 911 Plus conductivitytemperature-depth (CTD) system, mounted on a General Oceanics rosette sampler, equipped with 121 Niskin bottles. Chlorophyll a (chl a) concentrations were determined fluorometrically (Parsons et al. 1984) using a Turner Design fluorometer after pigment extraction overnight with $90 \%$ acetone. Samples for the determination of the dissolved inorganic phosphate (DIP; $\mathrm{PO}_{4}{ }^{3-}$ ), total dissolved phosphorus (TP), and the nitrate plus nitrite $\left(\mathrm{NO}_{3}{ }^{-}+\mathrm{NO}_{2}^{-}\right)$concentrations were kept frozen until analyzed in a Bran + Luebbe AA3 autoanalyzer following standard spectrophotometric methods (Hansen \& Koroleff 1999). Ammonium was measured according to Kérouel \& Aminot (1997).

Trace metal sampling and analysis. Surface seawater (1 m depth) samples were collected from a Zodiac deployed $2 \mathrm{~km}$ away from the research vessel in order to avoid contamination of the samples. Seawater was pumped through acid-cleaned Teflon tubing coupled to a C-flex tubing (for the Cole-Parmer 
peristaltic pump head), filtered through an acidcleaned polypropylene cartridge filter $(0.22 \mu \mathrm{m}$; MSI, Calyx $\left.{ }^{\circledR}\right)$, and collected in a 0.51 low-density polyethylene plastic bottle. Samples were acidified on board to $\mathrm{pH}<2$ with Ultrapure-grade $\mathrm{HCl}$ (Merck) in a class-100 HEPA laminar flow hood, and stored for at least one month before extraction. Metals $(\mathrm{Fe}, \mathrm{Mo}$, and V) were pre-concentrated by the APDC/DDDC organic extraction method of Bruland et al. (1979), and analyzed by ICP-AES (Perkin Elmer Optima 5300 DV). The accuracy of the pre-concentration method and analysis was established using Seawater Reference Material for Trace Elements (NASS5, NRCCNRC) with recoveries for samples from THRESHOLDS I and II of Fe: 94.9 and $95.5 \%$; Mo: 97.9 and $96.8 \%$; V: 84.8 and $107.8 \%$, respectively. Aerosol samples were collected using a high-volume collector (MCV: CAV$\mathrm{A} / \mathrm{HF}$ ) with a plastic filter holder into an acid-washed cellulose filter (Whatman 41). A microwave acid digestion procedure (Pekney \& Davidson 2005) followed by ICP-AES (Perkin Elmer, Optima 5300 DV) was used to measure total Fe levels in the aerosol filters.

Trichodesmium sp. counts, $\mathrm{N}_{2}$ fixation rates, $\delta^{15} \mathrm{~N}$ and particulate organic nitrogen. Trichodesmium abundance was determined during THRESHOLDS I and II. Samples were taken from vertical plankton hauls using a plankton net of $50 \mu \mathrm{m}$ pore size and casted down to the depth of the deep chlorophyll maximum (DCM), which varied from 30 to $130 \mathrm{~m}$ (depending on the station). The vertical plankton hauls were done 1 to 3 times and recovered at a speed of $20 \mathrm{~m} \mathrm{~min}^{-1}$. The sample volumes were pooled (amounting to $\sim 200 \mathrm{ml}$ of concentrated plankton cast samples from each station, wherein $60 \mathrm{ml}$ was preserved with $40 \mathrm{ml}$ buffered formaldehyde [at $4 \%$ final conc.]). The rest of the fresh unpreserved sample was used for determination of $\mathrm{N}_{2}$ fixation rates as described below. The fixed samples were stored at room temperature until identification and counting of Trichodesmium sp. using the Utermöhl technique (Lund et al. 1958) and the recommendations contained in the UNESCO manual (Hasle 1978). The samples (total fixed volume of $100 \mathrm{ml}$ ) were allowed to settle for $24 \mathrm{~h}$, and filaments were counted on the full settling chamber using an inverted microscope. When estimating the abundances of Trichodesmium sp., the total volume of water casted, the diameter of the plankton net, the depth of each cast, and the fraction of the pooled concentrated sample counted, were taken into account.

During both cruises, $\mathrm{N}_{2}$ fixation rates were measured using the acetylene reduction assay (ARA) (Stal 1988, Capone 1993) in surface water samples (5 m depth) collected using 201 Niskin bottles and in the plankton cast samples. During THRESHOLDS II, the surface water samples were also fractionated through 12 $\mu \mathrm{m}$ polycarbonate isopore filters in order to measure the $\mathrm{N}_{2}$ fixation in this fraction. Six 21 samples from surface waters (whole and fractionated to $<12 \mu \mathrm{m}$ ) and six $20 \mathrm{ml}$ subsamples of pooled concentrated samples from plankton net casts were filtered (pressure $<100 \mathrm{~mm} \mathrm{Hg}$ to minimize disruption of cells) through Whatman GF/F filters and assayed for acetylene reduction. The filters were placed in $10 \mathrm{ml} \mathrm{crimp}$ top vials, humidified with $\sim 0.5 \mathrm{ml}$ filtered GF/F seawater, and sealed with a rubber stopper and an aluminum cap. After sealing, $2 \mathrm{ml}$ of acetylene were injected using gas-tight Hamilton syringes. The vials

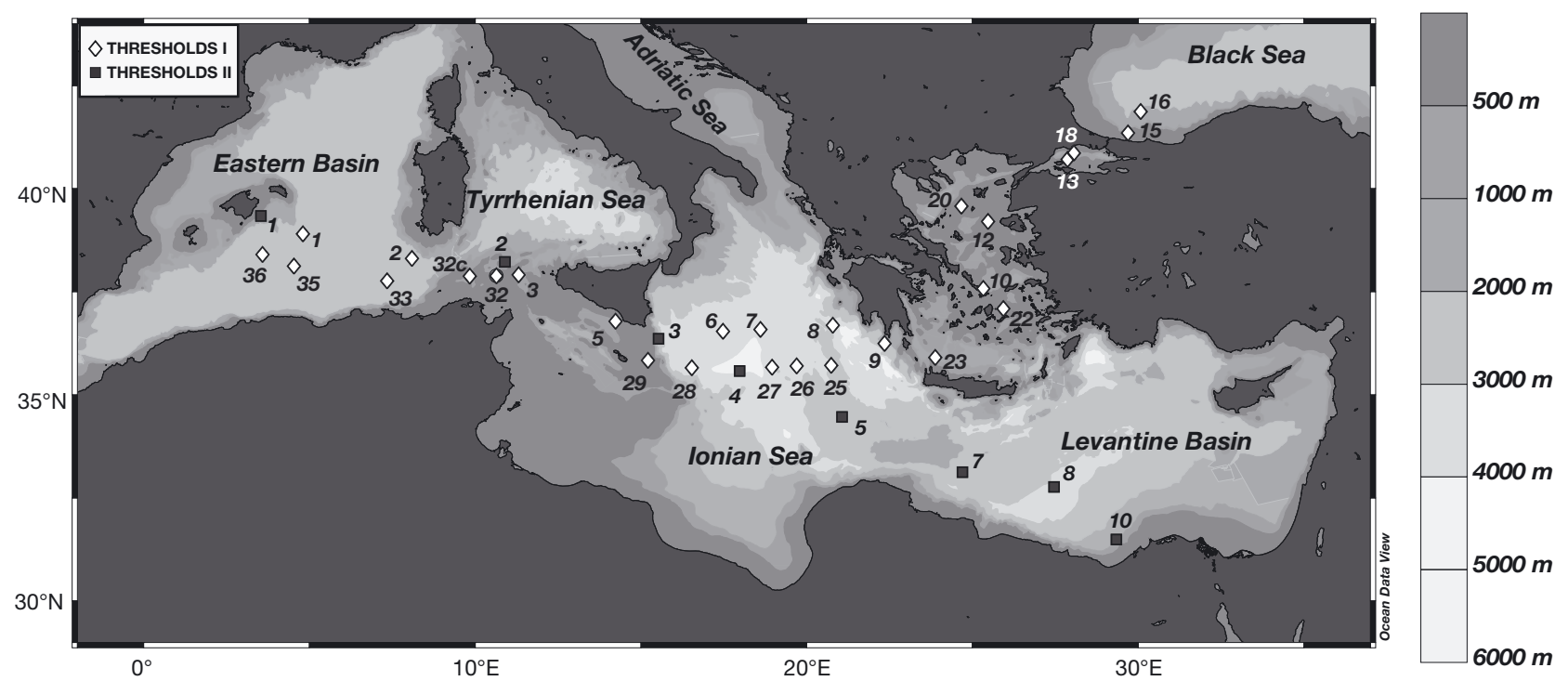

Fig. 1. Location of the stations during THRESHOLDS I carried out during June 2006 and THRESHOLDS II carried out during May 2007, where Trichodesmium sp. abundance and $\mathrm{N}_{2}$ fixation rates were determined 
were subsequently incubated ( 3 in the dark and 3 at ambient light attenuated to the light intensity at $5 \mathrm{~m}$ depth by using a neutral density screen) for $3 \mathrm{~h}$ (09:00 to $12: 00 \mathrm{~h}$ ) in on-deck aquaria with running circulating seawater to keep ambient temperature. After incubation, the headspace of the incubation vials was sampled using a gas-tight Hamilton syringe and transferred to and stored in evacuated Hungate tubes until analysis on land. The rubber stoppers of the Hungate tubes were further sealed with melted candle wax to minimize gas losses. Ethylene $\left(\mathrm{C}_{2} \mathrm{H}_{4}\right)$ and acetylene $\left(\mathrm{C}_{2} \mathrm{H}_{2}\right)$ were measured using a gas chromatograph (Agilent Technologies, model HP-5890) equipped with a flame ionization detector (FID), previously calibrated with standard $\mathrm{C}_{2} \mathrm{H}_{4}$ in helium and $\mathrm{C}_{2} \mathrm{H}_{2}$ at $4.157 \mu \mathrm{mol} \mathrm{C}_{2} \mathrm{H}_{4} \mathrm{l}^{-1}$ and $40.750 \mathrm{mmol} \mathrm{l}^{-1}$ original concentrations (Carburos Metalicos). The column was a Varian wide-bore column (ref. CP7584) packed with CP-PoraPLOT U $(27.5 \mathrm{~m}$ length, $0.53 \mathrm{~mm}$ inside diameter, $0.70 \mathrm{~mm}$ outside diameter, $20 \mu \mathrm{m}$ film thickness). Helium was used as the carrier gas at a flow rate of $30 \mathrm{ml} \mathrm{min}^{-1}$. Hydrogen and air flow rates were set at 60 and $400 \mathrm{ml} \mathrm{min}^{-1}$, respectively. The split flow was used so that the carrier gas flow through the column was at $4 \mathrm{ml} \mathrm{min}^{-1}$ at a pressure of 5 psi. Oven, injection and detector temperatures were set at 52 , 120 , and $170^{\circ} \mathrm{C}$, respectively. To determine the detection limit of the method, we considered the analyses of 8 blanks ( 4 sets done during THRESHOLDS I, and 4 sets done during THRESHOLDS II). The blanks were treated and calculated the same way as the samples. The detection limit was set as $3 \times$ the standard deviation of the blanks. The results (production of $\mathrm{C}_{2} \mathrm{H}_{4}$ from $\mathrm{C}_{2} \mathrm{H}_{2}$ ) are considered significant when the production of $\mathrm{C}_{2} \mathrm{H}_{4}$ was $>3 \times$ the standard deviation of the contaminating $\mathrm{C}_{2} \mathrm{H}_{4}$ in the $\mathrm{C}_{2} \mathrm{H}_{2}$. The detection limits for $\mathrm{C}_{2} \mathrm{H}_{4}$ production for THRESHOLDS I and II cruises were 0.22 and $0.022 \mathrm{nmol} \mathrm{C}_{2} \mathrm{H}_{4}$, respectively. Taking into account the maximum volume of water filtered in each cruise and incubation times, the detection limits for THRESHOLDS I and II cruises translates to $1.4 \times 10^{-3}$ and $1.5 \times 10^{-4} \mathrm{nmol} \mathrm{N}_{2} \mathrm{~m}^{-3} \mathrm{~h}^{-1}$, respectively.

$\delta^{15} \mathrm{~N}$ and total particulate organic nitrogen (PON) were analyzed in THRESHOLDS I from 1.5 to 51 surface water $(5 \mathrm{~m}$ depth) filtered on pre-combusted $(6 \mathrm{~h}$, $550^{\circ} \mathrm{C}$ ) Whatman GF/F filters. The filters were washed three times with $5 \mathrm{ml}$ Milli-Q in order to remove salts and were subsequently freeze-dried and stored at $-20^{\circ} \mathrm{C}$ until analysis. PON was analyzed using a Carlo Erba Instruments FLASH 1112 elemental analyzer. Nitrogen isotope ratios were determined using a Thermofinnigan Delta Plus isotope ratio mass spectrometer connected on-line to the Carlo Erba Instruments FLASH 1112 elemental analyzer. Data are expressed in the conventional delta notation: $\delta^{15} \mathrm{~N}_{\text {sample }}(\%)=\left[\left(R_{\text {sample }}-R_{\text {standard }}\right) / R_{\text {standard }}-1\right] \times 1000$

where $R$ is the ratio of ${ }^{15} \mathrm{~N}$ to ${ }^{14} \mathrm{~N}$, and reported relative to air $\mathrm{N}_{2}$ (standard). Average reproducibility based on duplicate measurements was $<0.2 \%$.

Data and statistical analyses. The acetylene reduction rates were calculated following the equations in Stal (1988) using acetylene as an internal standard, which circumvents inaccuracies due to gas losses during experimental handling, storage, and transport. Acetylene reduction was converted to $\mathrm{N}_{2}$ fixation using the conversion factor of acetylene reduced: $\mathrm{N}_{2}$ reduced of $4: 1$ (Jensen \& Cox 1983). Normal distribution of data was checked with the Shapiro-Wilk test (Shapiro \& Wilk 1965), and, if necessary, data were logarithmically transformed prior to analyses. Pearson correlation analyses were used to determine the correlations between $\mathrm{N}_{2}$ fixation rates, $\delta^{15} \mathrm{~N}-\mathrm{PON}$, total PON and Trichodesmium sp. abundance and the various physico-chemical factors measured (temperature, aerosol $\mathrm{Fe}$, dissolved $\mathrm{Fe}, \mathrm{V}$ and $\mathrm{Mo}, \mathrm{PO}_{4}{ }^{3-}, \mathrm{TP}, \mathrm{NO}_{3}{ }^{-}+\mathrm{NO}_{2}^{-}$). The statistical analyses were performed using the SPSS program.

\section{RESULTS}

Fig. 2 shows the distribution of sea surface temperature $\left(\mathrm{SST}^{\circ}{ }^{\circ} \mathrm{C}\right)$ and salinity (psu) during THRESHOLDS I (June 2006) and THRESHOLDS II (May 2007). During THRESHOLDS I, SST were generally higher (18.5 to $24.8^{\circ} \mathrm{C}$, Fig. 2A) than THRESHOLDS II (17.6 to $21.8^{\circ} \mathrm{C}$, Fig. $2 \mathrm{C}$ ). Salinity ranges were generally similar in both cruises (37.1 to $39.3 \mathrm{psu}$ ) except for lower salinity values in the Marmara Sea and adjacent inland Black Sea during THRESHOLDS I (Fig. 2B,D). During THRESHOLDS II, the eastern basin of the Mediterranean Sea revealed lower SST and salinity than the western part, while during THRESHOLDS I, SST and salinity did not differ much between the eastern and western basin (Fig. 2). During THRESHOLDS $\mathrm{I}$, the concentrations of $\mathrm{NO}_{3}{ }^{-}+$ $\mathrm{NO}_{2}{ }^{-}$in the upper $200 \mathrm{~m}$ varied from below detection to $1.01 \mu \mathrm{mol} \mathrm{N} \mathrm{l^{-1 }}$ at $5 \mathrm{~m}$, and increasing with depth to $8.34 \mu \mathrm{mol} \mathrm{N} \mathrm{^{-1 }}$ at $200 \mathrm{~m}$. During THRESHOLDS II, the concentrations of $\mathrm{NO}_{3}{ }^{-}+\mathrm{NO}_{2}{ }^{-}$varied between 0.09 and $0.42 \mu \mathrm{mol} \mathrm{N} \mathrm{^{-1 }}$ at $5 \mathrm{~m}$ and generally increased with depth (data not shown). Higher values of $\mathrm{NO}_{3}{ }^{-}+\mathrm{NO}_{2}{ }^{-}$ were found during THRESHOLDS I in the eastern stations, and during THRESHOLDS II in the western stations. During THRESHOLDS I, $\mathrm{PO}_{4}{ }^{3-}$ concentrations ranged below detection to $26.37 \mu \mathrm{mol} \mathrm{P} \mathrm{l^{-1 }}$ (in the eastern part of the Mediterranean Sea) without a clear variation with depth. TP varied from 0.05 to $0.50 \mu \mathrm{mol} \mathrm{P} \mathrm{l}^{-1}$, and increased with depth to $5.35 \mu \mathrm{mol} \mathrm{P} \mathrm{^{-1 }}$ at $200 \mathrm{~m}$ (data not shown). During THRESHOLDS II, $\mathrm{PO}_{4}{ }^{3-}$ concentrations also varied from below the detection limit to $0.13 \mu \mathrm{mol}$ 

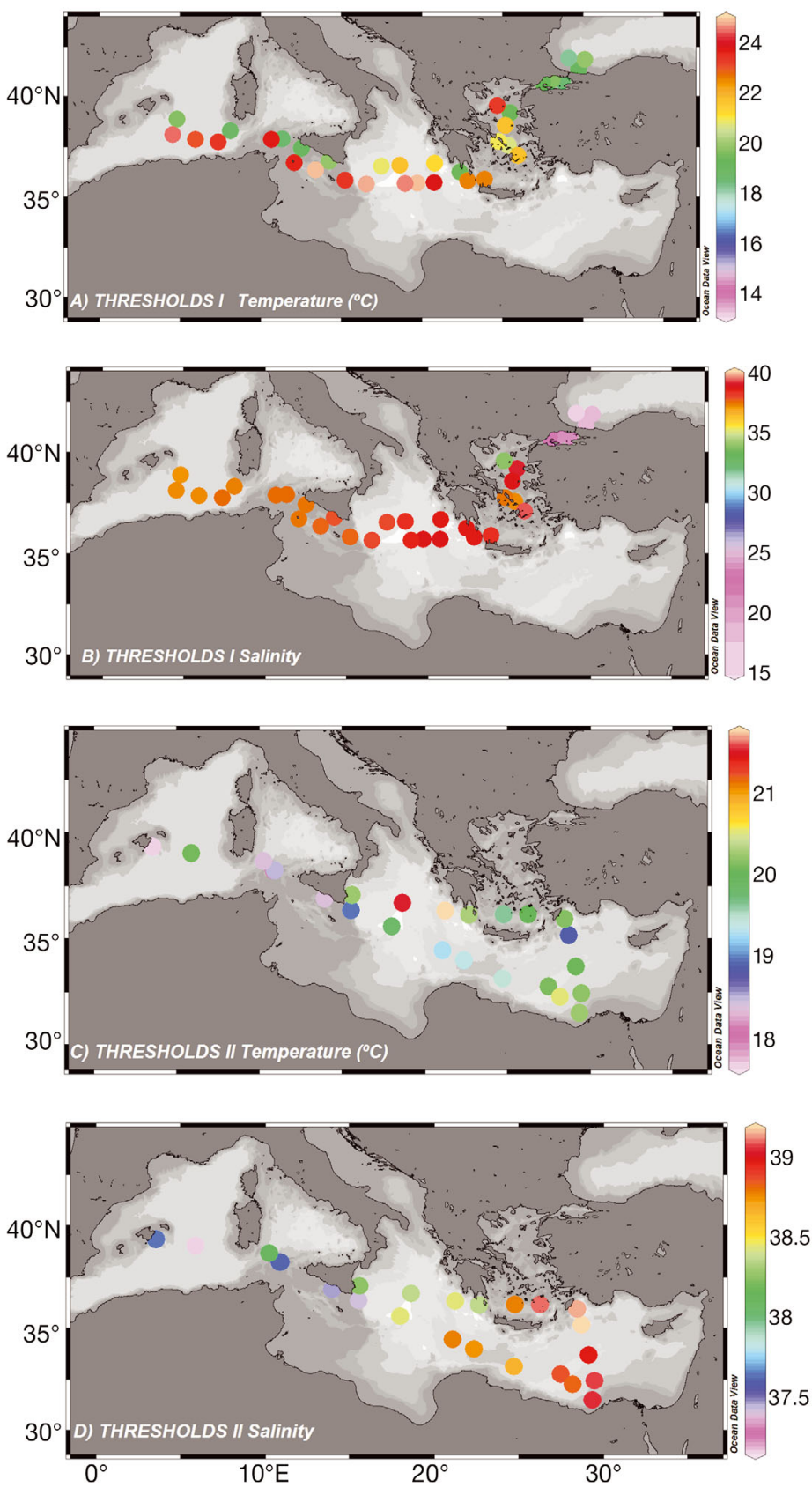

Fig. 2. Surface distributions of $(A, C)$ temperature and $(B, D)$ salinity along the west-east transects in the Mediterranean Sea during $(\mathrm{A}, \mathrm{B})$ THRESHOLDS I and $(\mathrm{C}, \mathrm{D})$ THRESHOLDS II

$\mathrm{P}^{-1}$, whereas TP varied from 0.15 to $0.53 \mu \mathrm{mol} \mathrm{P}^{-1}$ at 5 $\mathrm{m}$ without a clear variation with depth. During THRESHOLDS II, $\mathrm{NH}_{4}{ }^{+}$concentrations at $5 \mathrm{~m}$ varied from 0.02 to $0.25 \mu \mathrm{mol} \mathrm{N} \mathrm{^{-1 }}$ without a clear variation with depth (data not shown). Chl a profiles during the THRESHOLDS cruises can be found in Regaudie-de-Gioux et al. (2009). During THRESHOLDS I, chl a concentration varied between $0.1 \mathrm{mg} \mathrm{chl} \mathrm{a} \mathrm{m}^{-3}$ at $5 \mathrm{~m}$ to $7.5 \mathrm{mg} \mathrm{chl} \mathrm{a} \mathrm{m}^{-3}$ in the DCM. Lower chlorophyll concentrations were
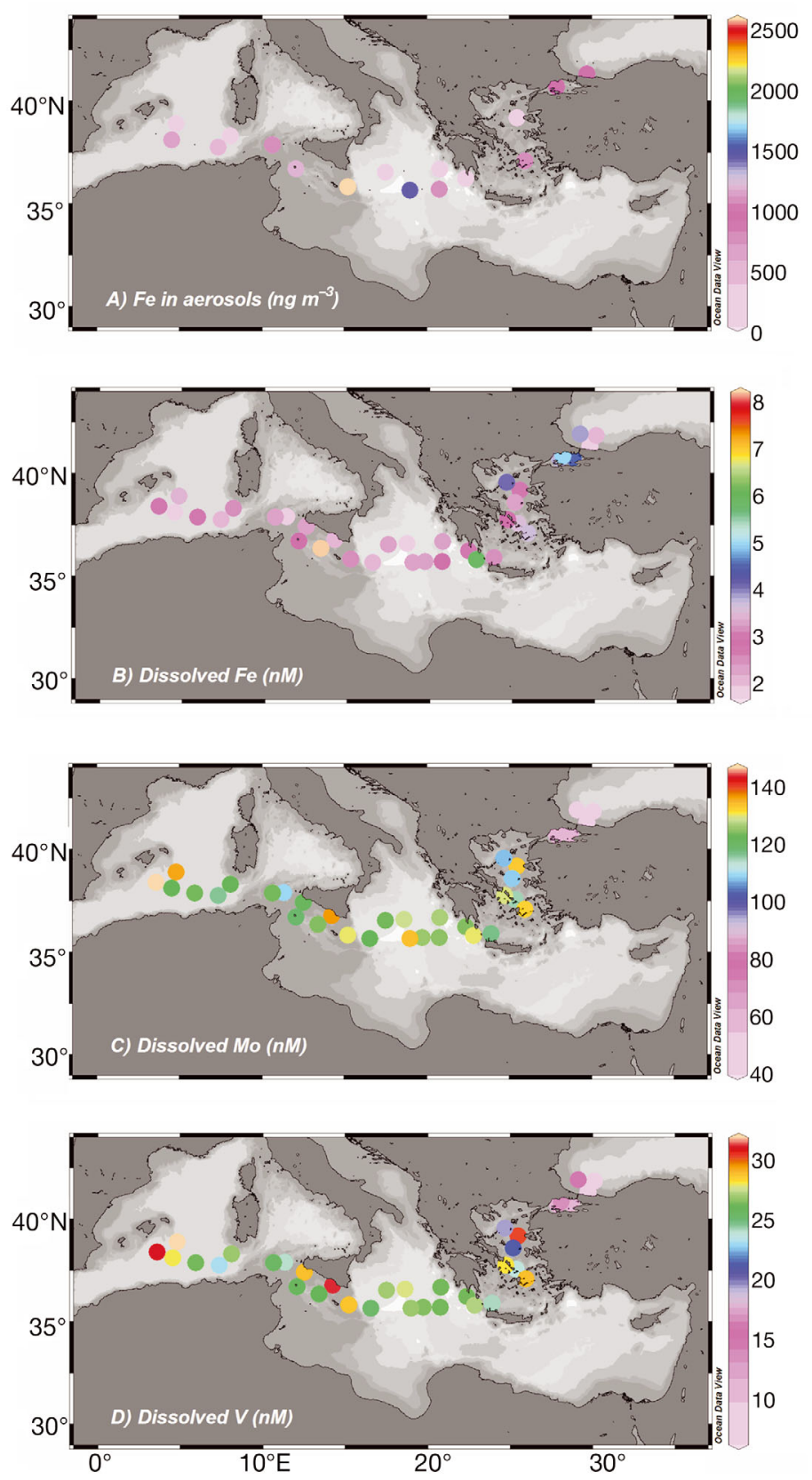

Fig. 3. Surface distributions of (A) iron (Fe) analyzed in aerosol samples $\left(\mathrm{ng} \mathrm{m}^{-3}\right)$, (B) dissolved Fe (nM), (C) dissolved molybdenum (Mo) (nM), and (D) dissolved vanadium (V) (nM) along the west-east transects in the Mediterranean Sea during THRESHOLDS I

found during THRESHOLDS II, which varied from $0.02 \mathrm{mg}$ chl $a \mathrm{~m}^{-3}$ at $5 \mathrm{~m}$ to $1.8 \mathrm{mg} \mathrm{chl} a \mathrm{~m}^{-3}$ in the DCM.

$\mathrm{Fe}$ in the aerosols sampled during THRESHOLDS I ranged from 43 to $2607 \mathrm{ng} \mathrm{m}^{-3}$ air filtered. The highest amount was found at Stn 29 in the western basin (Figs. 1 \& 3A). During THRESHOLDS I, dissolved Fe concentration at $5 \mathrm{~m}$ ranged from 1.7 to $8.2 \mathrm{nM}$, without a clear trend along the west-east transect (Fig. 3B). During THRESHOLDS II, dissolved Fe concentration at $5 \mathrm{~m}$ 

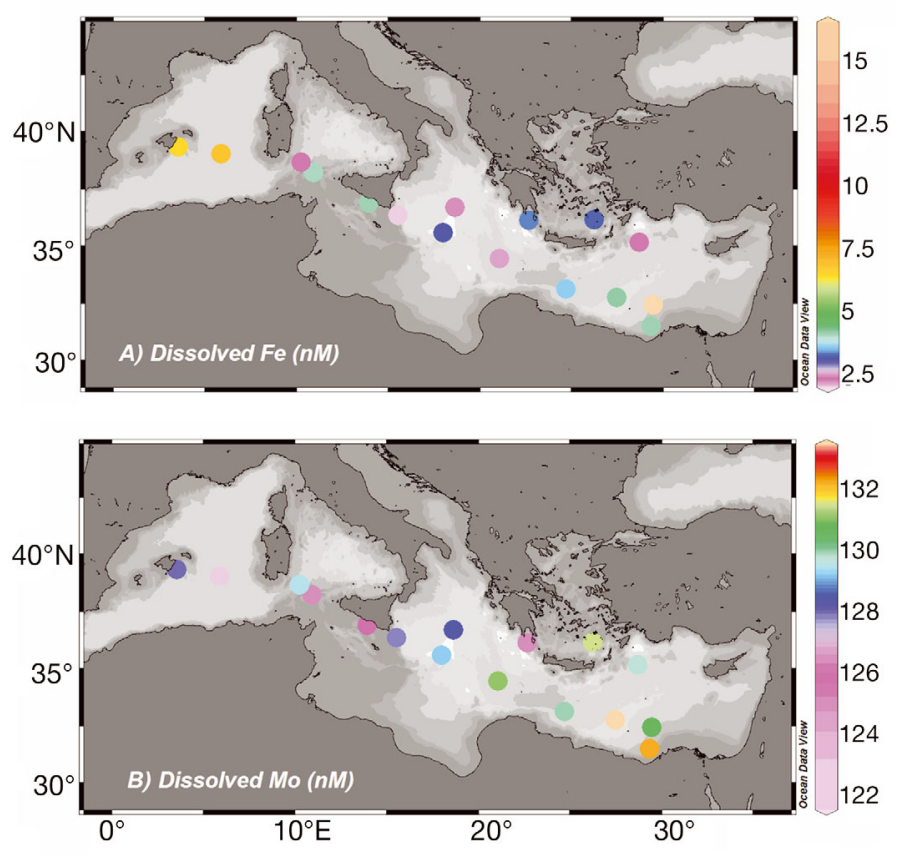

Fig. 4. Surface distributions of (A) dissolved iron (Fe) (nM) and (B) dissolved molybdenum (Mo) (nM) along the west-east transects in the Mediterranean Sea during THRESHOLDS II

ranged from 1.87 to $6.82 \mathrm{nM}$ (with only one high value of $16 \mathrm{nM}$ ) (Fig. 4A). During THRESHOLDS I, the concentrations of dissolved molybdenum varied from 41 to $147 \mathrm{nM}$, with the lowest concentrations occurring at the higher latitude stations (Fig. 3C). During THRESHOLDS II, molybdenum concentrations were more or less constant (128.6 $\pm 3.1 \mathrm{nM}$; Fig. 4B). Vanadium levels were also quite variable during THRESHOLDS I and ranged from 6.4 to $32 \mathrm{nM}$, with the lowest values occurring in the higher latitude stations (Fig. 3D).

The abundance of Trichodesmium sp. in stations during THRESHOLDS I ranged from 0.5 to 692 trichomes $\mathrm{m}^{-3}$ over the depth of the vertical hauls (average from surface down to DCM). The very high value was observed at Stn 32c (close to Stn 32) (Fig. 5C). During THRESHOLDS II, the abundance varied between 4 and 41 trichomes $\mathrm{m}^{-3}$ (Fig. 6D). During THRESHOLDS $\mathrm{I}$, the abundance of Trichodesmium sp. was significantly correlated with $\mathrm{N}_{2}$ fixation in the plankton cast samples (Pearson $r=0.73, p<0.05, n=11$ ). During THRESHOLDS II, when $\mathrm{N}_{2}$ fixation was also measured in the $<12 \mu \mathrm{m}$ fraction in surface water samples, the rates were similar to those measured in the non-size fractionated whole surface water samples except at one station (Fig. 6A,B). $\mathrm{N}_{2}$ fixation measured in the light and dark were significantly correlated with each other $(p<0.05)$ in each of the fractions in both cruises. $\mathrm{N}_{2}$ fixation was highest in whole surface water samples measured in the dark during THRESHOLDS I at Stn 18 (Fig. 5A), and it
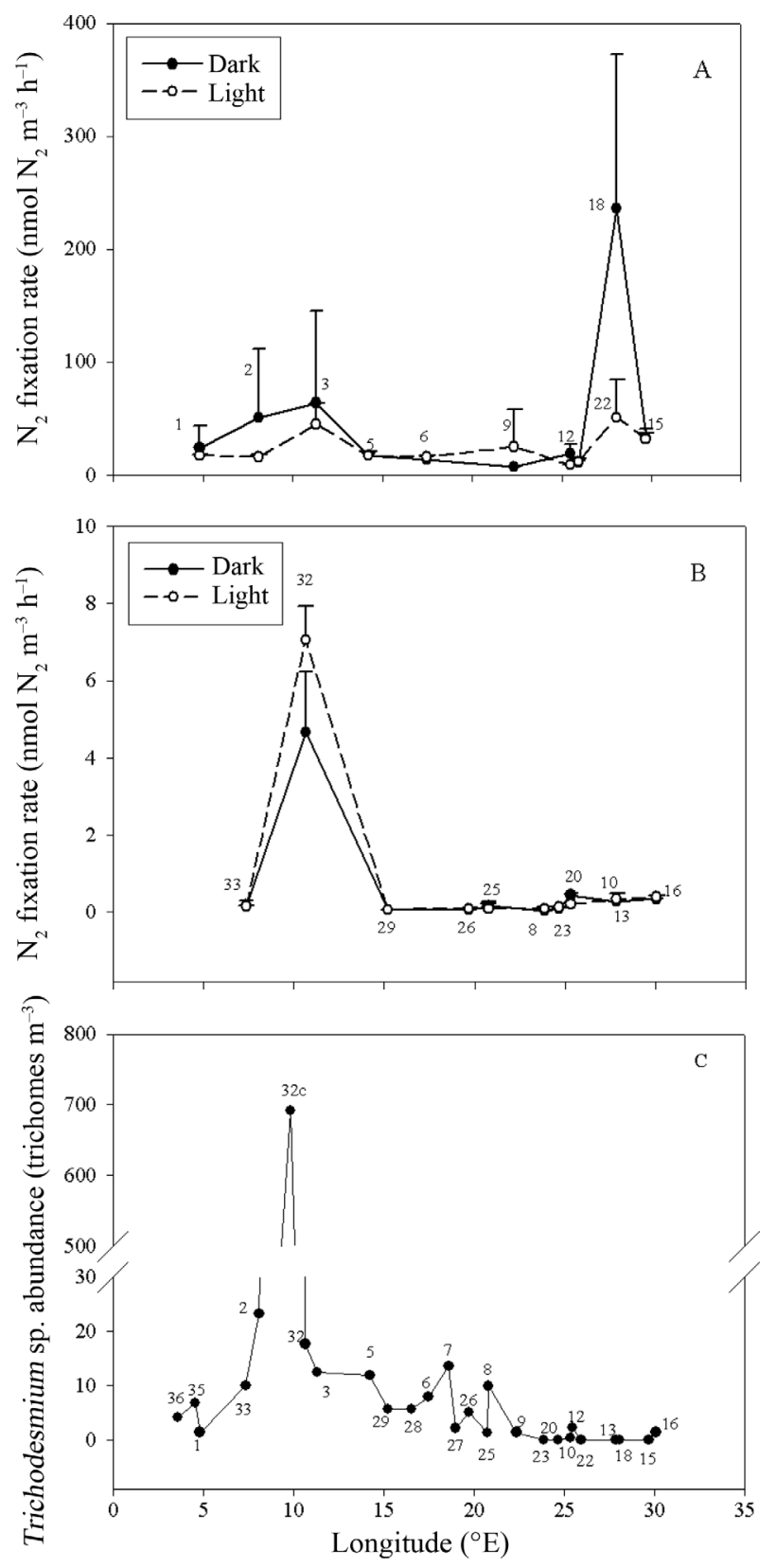

Fig. 5. $\mathrm{N}_{2}$ fixation rates in (A) whole discrete surface samples, and (B) plankton cast samples integrated from surface to DCM, measured in the light and in the dark, and (C) Trichodesmium sp. abundance (>50 $\mu \mathrm{m})$ during THRESHOLDS I. Error bars in (A) and (B) denote standard deviation of triplicate samples

coincides with relatively high TP and dissolved Fe concentrations (Fig. 7). $\delta^{15} \mathrm{~N}$ values ranged between +5.3 and $+12.8 \%$, with no clear trends from west-east transect during THRESHOLDS I (Fig. 8A). During THRESHOLDS I, particulate organic nitrogen (PON) ranged from 0.0003

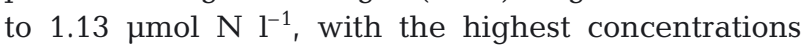
occurring in the eastern part of the transect (Fig. 8B). 

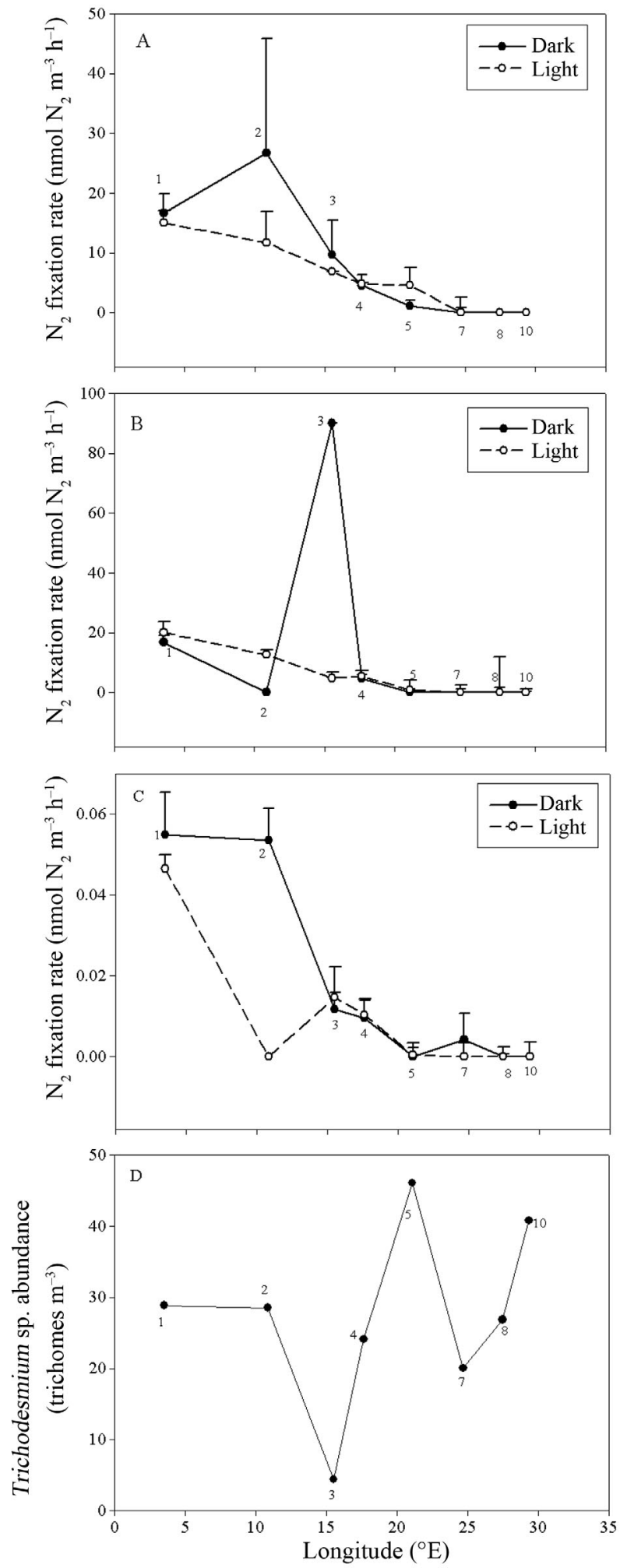

Fig. 6. $\mathrm{N}_{2}$ fixation rates in (A) whole discrete surface samples, (B) $<12 \mu \mathrm{m}$ discrete surface samples, and (C) plankton cast samples integrated from surface to DCM, measured in the light and in the dark, and (D) Trichodesmium sp. abundance $(>50 \mu \mathrm{m})$ during THRESHOLDS II. Error bars in (A) and (B) denote standard deviation of triplicate samples
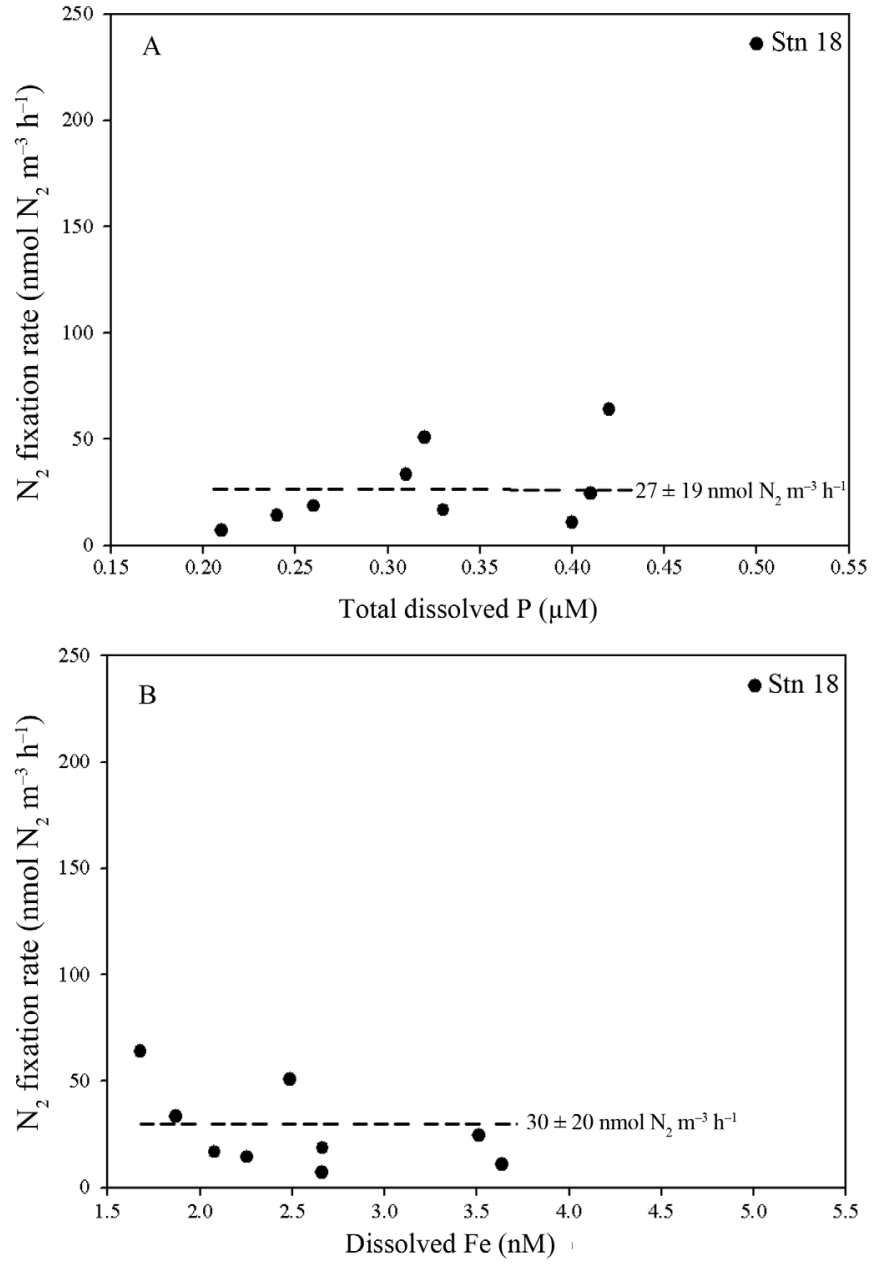

Fig. 7. Plot between $\mathrm{N}_{2}$ fixation rates in whole discrete surface samples measured in the dark during THRESHOLDS I with (A) total dissolved phosphorus (TP) concentrations and in which the average is $27 \pm 19 \mathrm{nmol} \mathrm{N}_{2} \mathrm{~m}^{-3} \mathrm{~h}^{-1}$ at $\mathrm{TP}<0.45 \mu \mathrm{M}$, and (B) with dissolved $\mathrm{Fe}$ concentrations and in which the average is $30 \pm 20 \mathrm{nmol} \mathrm{N} \mathrm{m}^{-3} \mathrm{~h}^{-1}$ at dissolved Fe $<4 \mathrm{nM}$. Highest values were found at Stn 18 (Sea of Marmara, adjacent to the Black Sea)

PON correlated significantly with $\mathrm{N}_{2}$ fixation in whole, unfractionated samples measured in the light and dark (Pearson $r=0.72$ and $r=0.80$, respectively; $\mathrm{p}<0.05, \mathrm{n}=9$ ).

\section{DISCUSSION}

Basin-wide occurrence of the key marine diazotrophic filamentous cyanobacterium Trichodesmium has not been reported previously in the Mediterranean Sea. Here we report on the presence of this important $\mathrm{N}_{2}$ fixing organism throughout the Mediterranean Sea except at $>35^{\circ} \mathrm{N}, 20^{\circ} \mathrm{E}$ (Aegean Sea and Black Sea) where Trichodesmium sp. was absent (Figs. 1 \& 5C). 

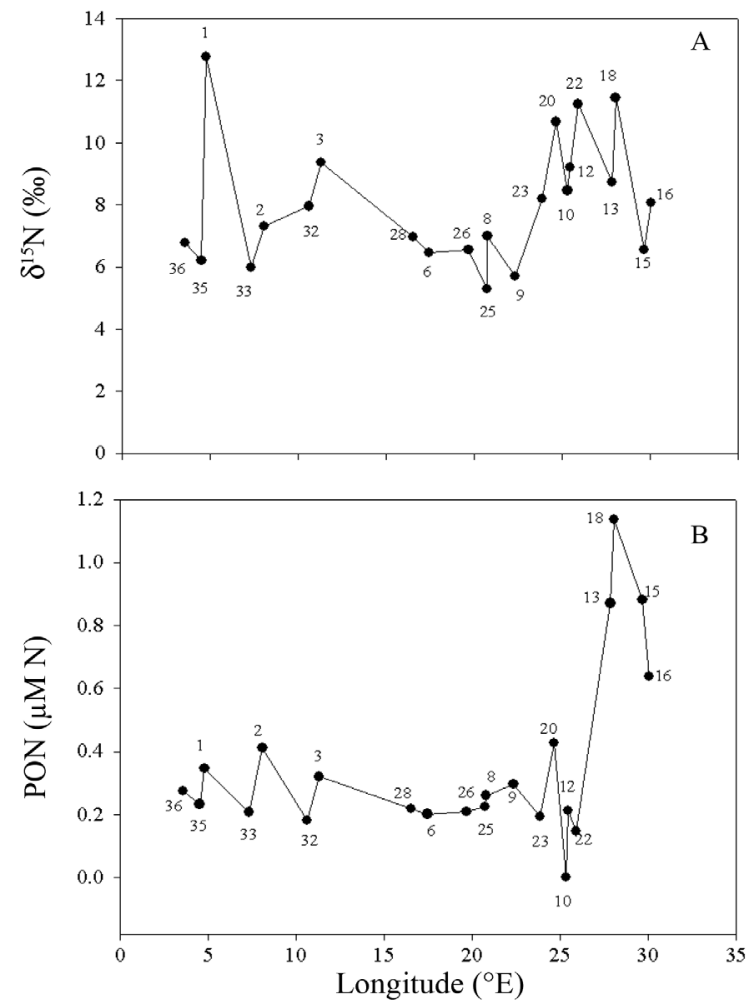

Fig. 8. (A) $\delta^{15} \mathrm{~N}$ values, and (B) PON concentrations in surface water samples during THRESHOLDS I

When present in the Mediterranean Sea, Trichodesmium sp. occurred in much lower abundances $\left(<50\right.$ trichomes $\left.\mathrm{m}^{-3}\right)$ than in other regions where basinscale surveys of Trichodesmium sp. have been conducted (Tyrell et al. 2003, Davis \& McGillicuddy 2006, Fernández et al. 2010). The question to be answered was whether the occurrence of Trichodesmium sp. (which occurred as single trichomes rather than in the typical colony forms of this organism: tufts or puffs) in the Mediterranean Sea is due to drift or to local growth of the organism. It has been suggested that the occurrence of Trichodesmium sp. at higher latitudes with water temperatures $<20^{\circ} \mathrm{C}$ appears to be due to drift and not due to local net growth based on the direct physiological effects of temperature on diazotrophic growth of Trichodesmium sp. (Breitbarth et al. 2007). During the THRESHOLDS cruises, only at one station in the Tyrrhenian Sea (between Sardinia and Sicily) where temperature was $>20^{\circ} \mathrm{C}$ (Fig. 2), Trichodesmium sp. abundance was high ( 700 trichomes $\left.\mathrm{m}^{-3}\right)$ (Figs. $1 \& 5 \mathrm{C}$ ). At the other stations, Trichodesmium sp. abundance was low (Figs. 5C \& 6D), and further investigations are needed to know whether these are drifted populations of Trichodesmium sp. or whether they proliferated locally.

Low numbers of Trichodesmium sp. in the Mediterranean basin, low rates of $\mathrm{N}_{2}$ fixation in plankton cast samples $(>50 \mu \mathrm{m})$ and the data of size-fractionated $\mathrm{N}_{2}$ fixation $(<12 \mu \mathrm{m}$ size fractions $)$ in discrete surface water samples indicate the presence of other $\mathrm{N}_{2}$ fixers in the region. These may be unicellular cyanobacteria (UCYN 2 -Fix lineage; Le Moal \& Biegala 2009) and/or Richelia intracelullaris (Venrick 1974), a heterocystous cyanobacterium occurring as an endosymbiont in the diatom Rhizosolenia whose diameter ranges from 2.5 to $170 \mu \mathrm{m}$ (Wimpenny 1966). A previous study has indicated a high diversity of diazotrophs, with a dominance of the cyanobacterium Richelia intracellularis associated with the diatom Hemiaulus hauckii in the Eastern Mediterranean (Levantine, off the Israeli coast) identified through molecular identification and expression of nifH, one of the structural genes of nitrogenase (Man-Aharonovich et al. 2007). $\mathrm{N}_{2}$-fixing heterotrophs may also be present in the water column because considerable rates of $\mathrm{N}_{2}$-fixation have been detected in samples incubated in the dark. Alternatively, the dark $\mathrm{N}_{2}$-fixation can be carried out by the phototrophs that can satisfy the energy and reducing equivalents demands by respiratory means, which explains the significant correlation $(\mathrm{p}<0.05)$ between $\mathrm{N}_{2}$ fixation rates measured in the light and dark in each of the fractions in both THRESHOLDS cruises.

Our data on $\mathrm{N}_{2}$ fixation rates based on the ARA for integrated samples of $>50 \mu \mathrm{m}$ (accounting for Trichodesmium sp.) are similar in range compared to the majority of recent published $\mathrm{N}_{2}$ fixation rates in the Mediterranean Sea for total community integrated samples based on ${ }^{15} \mathrm{~N}$ tracer experiments (Ibello et al. 2010, Bonnet et al. 2011, Yogev et al. 2011; Table 1). This suggests that total community integrated samples during the THRESHOLDS cruises (if taking into account the $<50 \mu \mathrm{m}$ fraction - whole water samples were only measured in discrete surface [5 $\mathrm{m}$ ] samples thus precluding comparisons with previous published estimates in the Mediterranean) could be higher than previous estimates in the Mediterranean Sea (Ibello et al. 2010, Bonnet et al. 2011, Yogev et al. 2011; Table 1). This can be due to differences in the techniques used between the THRESHOLDS cruises and other studies (ARA measures gross $\mathrm{N}_{2}$ fixation [Mulholland 2007] and the stable isotope ${ }^{15} \mathrm{~N}_{2}$ method measures net actual incorporated $\mathrm{N}_{2}$ into biomass [Montoya et al. 1996]) and/or temporal and spatial variability of the measurements. Also, different diazotroph groups might have been present at different times and they might have different physiologies. Nevertheless, $\mathrm{N}_{2}$ fixation in whole fractions on discrete surface samples measured using ARA during the THRESHOLDS cruises along the Mediterranean basin were low (from non detectable to $<500 \mathrm{nmol} \mathrm{N} \mathrm{m}{ }^{-3} \mathrm{~h}^{-1}$ ) compared to rates reported in other oligotrophic systems in the Atlantic Ocean. In whole fractions of discrete surface samples, 
up to $1000 \mathrm{nmol} \mathrm{N} \mathrm{m}^{-3} \mathrm{~h}^{-1}$ or $12 \mu \mathrm{mol} \mathrm{N} \mathrm{m} \mathrm{N}^{-3} \mathrm{~d}^{-1}$ (assuming 12 daylight $h$ ) were reported using the ${ }^{15} \mathrm{~N}_{2}$ method (Fernández et al. 2010).

The low $\mathrm{N}_{2}$ fixation rates across the Mediterranean basin found in this investigation agreed with the high natural $\delta^{15} \mathrm{~N}-\mathrm{PON}$ values (mean $\pm \mathrm{SD}$ : $8.04 \pm 2.03 \%$ ) across the Mediterranean basin. The ${ }^{15} \mathrm{~N} /{ }^{14} \mathrm{~N}$ approach has been used as an indication of $\mathrm{N}_{2}$ fixation. The utilization of nitrate is selective for the lighter isotope of nitrogen ${ }^{14} \mathrm{~N}$ and results in $\mathrm{N}$ products (biomass), which are depleted in ${ }^{15} \mathrm{~N}$ relative to the source nitrate. In closed systems, the remaining nitrate will progressively be enriched in ${ }^{15} \mathrm{~N}$, consequently producing biomass enriched in ${ }^{15} \mathrm{~N}$, and through mass-balance considerations, the ${ }^{15} \mathrm{~N} /{ }^{14} \mathrm{~N}$ ratio of biomass approaches that of the original nitrate source (Struck et al. 2001). $\mathrm{N}_{2}$ fixation is not selective for isotopes, and therefore the ${ }^{15} \mathrm{~N} /{ }^{14} \mathrm{~N}$ ratio of the biomass produced from fixed dinitrogen differs little from the substrate $\left(\mathrm{N}_{2}\right)$ and produces biomass of low $\delta^{15} \mathrm{~N}$ (approx. -2 to $0 \%$ ) (Struck et al. 2001). The natural $\delta^{15} \mathrm{~N}-\mathrm{PON}$ values displayed here were $>+5.3 \%$ with no clear trend from the westeast transect across the Mediterranean Sea. These values are higher than the values reported in a previous study $(-2.1$ to $+4.11 \%)$, displaying a decreasing gradient from west to east (Ibello et al. 2010).

Studies aiming at elucidating the effect of physicochemical factors on $\mathrm{N}_{2}$ fixation in the Mediterranean Sea are few, and the factors controlling $\mathrm{N}_{2}$ fixation in this basin are therefore not well understood. We made an attempt to correlate the $\mathrm{N}_{2}$ fixation data with physico-chemical factors (temperature, inorganic nutrients and trace metal [Fe, V, Mo] availability). None of these factors tested resulted in significant correlations with the measured $\mathrm{N}_{2}$ fixation rates here. However, sea surface temperature, which was significantly higher during THRESHOLDS I than in THRESHOLDS II ( $p<0.05$, independent $t$-test of means; Fig. 2), can be an important factor in explaining the significantly higher ( $\mathrm{p}<0.05$, independent $t$-test of means) $\mathrm{N}_{2}$ fixation rates of whole water surface samples during THRESHOLDS I than in THRESHOLDS II (Table 1). From previous studies in the ocean, phosphorus (Sohm et al. 2008), iron (Kustka et al. 2003) or a combination of both (Mills et al. 2004) are also known to limit $\mathrm{N}_{2}$ fixation. The Mediterranean Sea has been described as a phosphate-depleted basin (Ribera d'Alcalà et al. 2003) and inorganic phosphate $\left(\mathrm{PO}_{4}{ }^{3-}\right)$ concentrations, are often close to the detection limit. Hence, $\mathrm{P}$ could be an important limiting factor for Mediterranean biological $\mathrm{N}_{2}$ fixation activities. Contradictory reports have been published with regard to the role of P limitation in controlling biological $\mathrm{N}_{2}$ fixation in the Mediterranean. Microcosm experiments with DIP additions revealed that DIP was a key controlling factor in stations in the eastern and western basins (but not in the central basin) (Ridame et al. 2011). However, in the previous basin-wide experiment in the Mediterranean Sea (Ibello et al. 2010), and in the present study, no co-variation was found between $\mathrm{N}_{2}$ fixation rates and DIP nor dissolved organic $\mathrm{P}$ (DOP), which may be used as an alternative source of phosphorus by $\mathrm{N}_{2}$ fixers (Rees et al. 2006). Although we did not obtain evidence for a correlation on a basin-wide scale for the role of $\mathrm{P}$ in controlling biological $\mathrm{N}_{2}$ fixation in the Mediterranean Sea, we did observe high $\mathrm{N}_{2}$ fixation rates coinciding with high TP in one station (Stn 18 in the Sea of Marmara, adjacent to the Black Sea; Fig. 7A). This station showed a 1 order of magnitude higher rate of $\mathrm{N}_{2}$ fixation than the other stations which was more uniform $\left(27 \pm 19 \mathrm{nmol} \mathrm{N}_{2} \mathrm{~m}^{-3} \mathrm{~h}^{-1}\right)$ at a TP of $<0.45 \mu \mathrm{M}$ (Fig. 7A). PON was also highest at Stn 18 (Fig. 8B). Clearly more studies are needed to address the role of $\mathrm{P}$ in controlling biological $\mathrm{N}_{2}$ fixation in the Mediterranean.

The role of $\mathrm{Fe}$, the other possible controlling factor of $\mathrm{N}_{2}$ fixation, has been subject of investigations in the Mediterranean Sea (Ridame et al. 2011). The range of the extensive basin-wide surface concentrations of dissolved Fe (1.7 to $8.2 \mathrm{nM}$ and 1.87 to $6.82 \mathrm{nM}$ [with one high value of $16.7 \mathrm{nM}$ ] during THRESHOLDS I and II, respectively) is similar to what has been reported in previous studies in the Mediterranean Sea (e.g. 5.8 to $11.8 \mathrm{nM}$ in Saager et al. 1993, 0.13 to $4.8 \mathrm{nM}$ in Sarthou \& Jeandel 2001). The wide range of dissolved Fe concentration found in the present study suggests wide spatial variability of its distribution in the Mediterranean Sea. Previous studies have shown the impact of Saharan dust deposition on dissolved $\mathrm{Fe}$ in the Mediterranean Sea (Guerzoni et al. 1999, Guieu et al. 2002), and other studies have dealt with temporal variability of dust Fe dissolution in seawater in the Mediterranean Sea (Wagener et al. 2008). The source of the dissolved Fe and its spatial variability found during THRESHOLDS remains to be elucidated since no correlation was found between the Fe aerosol deposition and dissolved Fe $(p>0.05)$. Microscosm experiments conducted in the Mediterranean Sea showed no limitation by Fe (Ridame et al. 2011). However, we found that the highest $\mathrm{N}_{2}$ fixation rates that we observed in Stn 18 (Fig. 7B) coincided with one of the highest dissolved Fe concentrations measured in this basin-wide survey $(\sim 5 \mathrm{nM}$; Fig. 3B). Nevertheless, it is clear that the role of $\mathrm{Fe}$ in controlling $\mathrm{N}_{2}$ fixation activities in the Mediterranean remains to be elucidated.

Aside from $\mathrm{Fe}$, there are other bioactive trace metals that may play an important role in regulating $\mathrm{N}_{2}$ fixation, such as molybdenum (Mo) (Howarth \& Cole 1985, Marino \& Howarth 1990), and vanadium (V) both of which have not been investigated into much depth (Tovar-Sánchez \& Sañudo-Wilhelmy 2011). Here, we 


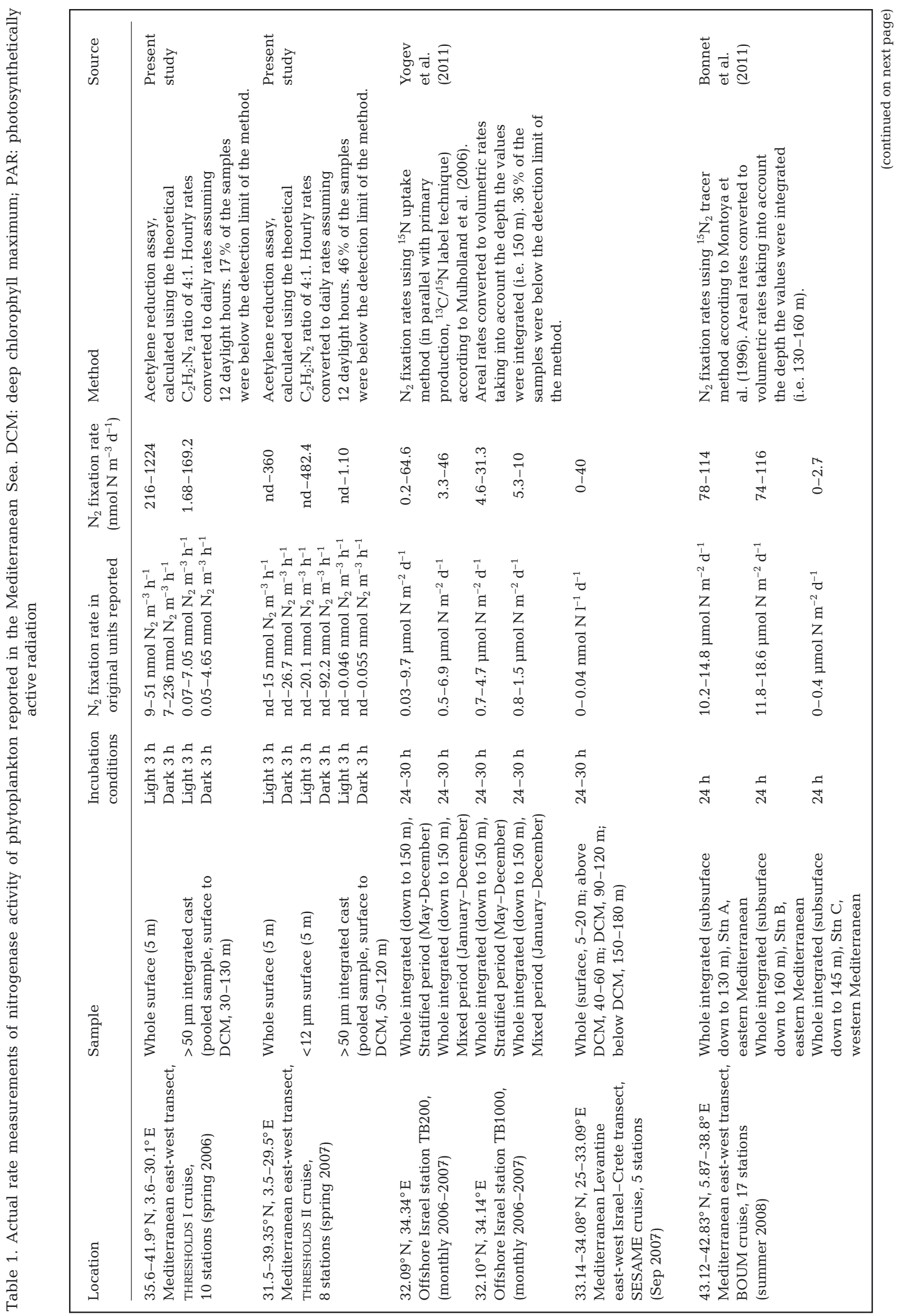




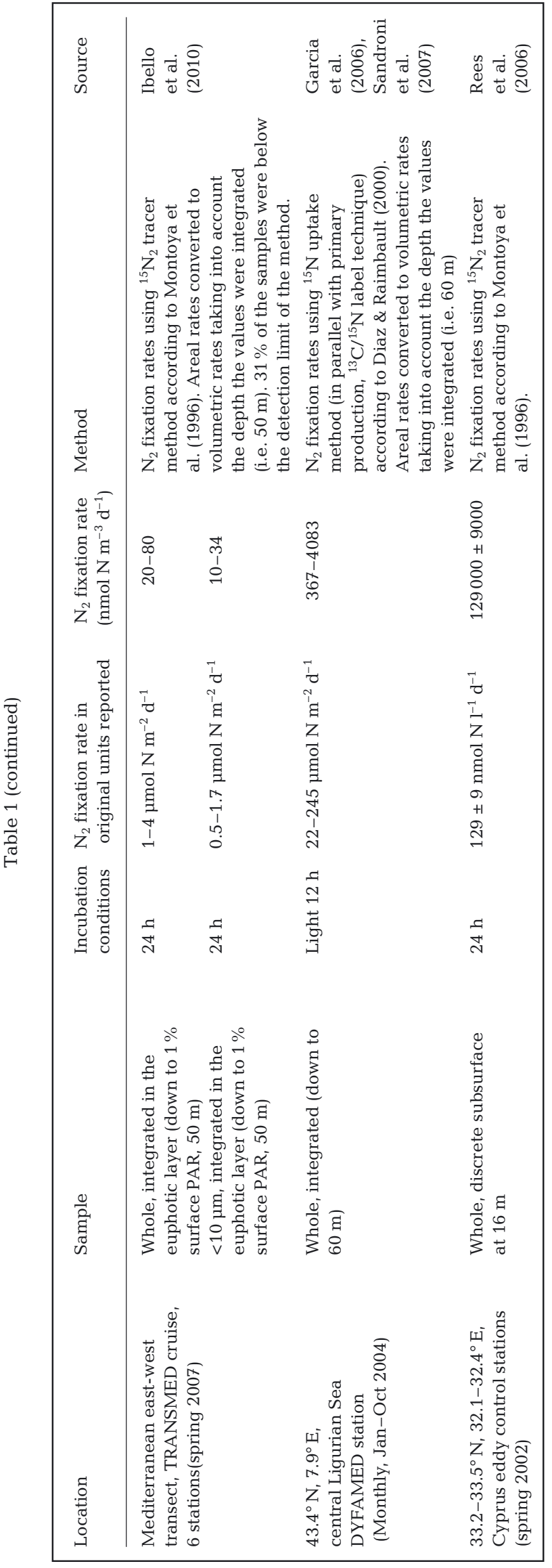

presented a basin-wide distribution of these micronutrients, but they did not show any notable spatial variability across the basin nor a correlation with $\mathrm{N}_{2}$ fixation rates.

Extensive biological $\mathrm{N}_{2}$ fixation in the Mediterranean Sea has been inferred from previous studies. Calculations imply a 7 to $41 \%$ contribution of biological $\mathrm{N}_{2}$ fixation to the Mediterranean Sea nitrogen budget (Béthoux \& Copin-Montégut 1986) and isotopic data indicate that biological $\mathrm{N}_{2}$ fixation contributes 46 to $70 \%$ of the eastern basin new nitrogen (Sachs \& Repeta 1999). Considering the recently increasing amount of data of actual rates of biological $\mathrm{N}_{2}$ fixation (Garcia et al. 2006, Sandroni et al. 2007, Ibello et al. 2010, Bonnet et al. 2011, Yogev et al. 2011, present study), the next step would be to re-estimate the contribution of biological $\mathrm{N}_{2}$ fixation to new nitrogen on a basin-wide scale and to re-assess the importance of this process in the Mediterranean Sea. Moreover, not only water column biological $\mathrm{N}_{2}$ fixation should be considered but also benthic $\mathrm{N}_{2}$ fixation. Benthic $\mathrm{N}_{2}$ fixation associated to Posidonia oceanica meadows can be an important source of new nitrogen. $P$. oceanica is an endemic angiosperm in the Mediterranean Sea, which occupies $50000 \mathrm{~km}^{2}$ (50\% occupation in the Mediterranean Sea floor) and globally covering $2 \%$ of the sea area (Béthoux \& Copin-Montégut 1986). To date, $\mathrm{N}_{2}$ fixation rates associated to $P$. oceanica meadows in the Mediterranean Sea have not been reported, yet preliminary data reveal high $\mathrm{N}_{2}$ fixation in the phyllosphere of $P$. oceanica (up to $1824 \mathrm{nmol} \mathrm{N} \mathrm{m}^{-2} \mathrm{~h}^{-1}$; Agawin et al. unpubl. data).

Acknowledgements. This work was supported by the project THRESHOLDS (CTM2005-24238-E) funded by the EU-FP6 and complementary actions from the Consejo Superior de Investigaciones Cientificas (CSIC), and Juan de la Cierva and Ramon y Cajal grant from the Spanish Ministry of Science and Innovation (MICINN) to N.S.R.A. We thank Juan Carlos Alonso for nutrient analyses and the crew of BIO García del Cid and the rest of the THRESHOLDS participants for cooperative work at sea. We also thank N. Monerris for her help in counting Trichodesmium sp., P. Ferriol for technical assistance and J. F. González (Serveis Cientificotècnics, UIB) for technical support with the ICP-AES. This is publication 5060 of NIOO-KNAW.

\section{LITERATURE CITED}

Berman-Frank I, Lundgren P, Chen Y, Küpper H, Kolber Z, Bergman B, Falkowski P (2001) Segregation of nitrogen fixation and oxygenic photosynthesis in the marine cyanobacterium Trichodesmium sp. Science 294: 1534-1537

Béthoux JP, Copin-Montégut G (1986) Biological fixation of atmospheric nitrogen in the Mediterranean Sea. Limnol Oceanogr 31:1353-1358

Béthoux JP, Morin P, Ruiz-Pino DP (2002) Temporal trends in nutrient ratios: chemical evidence of Mediterranean 
ecosystem changes driven by human activity. Deep-Sea Res II 49:2007-2016

Bonnet S, Grosso O, Moutin T (2011) Planktonic dinitrogen fixation in the Mediterranean Sea: a major biogeochemical process during the stratified period? Biogeosciences Discuss 8:1197-1225

Breitbarth E, Oschlies A, LaRoche J (2007) Physiological constraints on the global distribution of Trichodesmium sp. effect of temperature on diazotrophy. Biogeosciences 4: $53-61$

Bruland KW, Franks RP, Knauer G, Martin JH (1979) Sampling and analytical methods for the determination of copper, cadmium, zinc, and nickel in seawater. Anal Chim Acta 105:233-245

Capone DG (1993) Determination of nitrogenase activity in aquatic samples using the acetylene reduction procedure. In: Kemp PF, Sherr BF, Sherr EB, Cole JJ (eds) Handbook of methods in aquatic microbial ecology. Lewis Publishers, Boca Raton, FL

Davis CS, McGillicuddy DJ (2006) Transatlantic abundance of the $\mathrm{N}_{2}$ fixing colonial cyanobacterium Trichodesmium sp. Science 312:1517-1520

Diaz F, Raimbault P (2000) Nitrogen regeneration and dissolved organic nitrogen release during spring in a NW Mediterranean coastal zone (Gulf of Lions): implications for the estimation of new production. Mar Ecol Prog Ser 197:51-65

Fernández A, Mouriño-Carballido B, Bode A, Varela M, Marañon E (2010) Latitudinal distribution of Trichodesmium spp. and $\mathrm{N}_{2}$ fixation in the Atlantic Ocean. Biogeosciences 7:3167-3176

Fu FX, Bell PRF (2006) Factors affecting $N_{2}$ fixation by the cyanobacterium Trichodesmium sp. GBRTRLI101. FEMS Microbiol Ecol 45:203-209

Garcia N, Raimbault P, Gouze E, Sandroni V (2006) Fixation de diazote et production primaire en Méditerranée occidentale. Cr Biol 329:742-750

Guerzoni S, Chester R, Dulac F, Moulin C and others (1999) The role of atmospheric deposition in the biogeochemistry of the Mediterranean Sea. Prog Oceanogr 44:147-190

Guieu C, Bozec Y, Blain S, Ridame C, Sarthou G, Leblond N (2002) Impact of high Saharan dust inputs on dissolved iron concentrations in the Mediterranean Sea. Geophys Res Lett 29:1911 doi:10.1029/2001GL014454

Hansen HP, Koroleff F (1999) Determination of nutrients. In: Grasshoff K, Ehrhardt M, Kremling K (eds) Methods of seawater analysis, 3rd edn. Wiley-VCH, New York, NY

Hasle GR (1978) The inverted microscope method. In: Sournia A (ed) Phytoplankton manual. Monographs on oceanographic methodology, Vol 6. UNESCO, Paris

Howarth RW, Cole JJ (1985) Molybdenum availability, nitrogen limitation, and phytoplankton growth in natural waters. Science 229:653-655

Ibello V, Cantoni C, Cozzi S, Civitarese G (2010) First basinwide experimental results on $\mathrm{N}_{2}$ fixation in the open Mediterranean Sea. Geophys Res Lett 37:L03608 doi: 10.1029/2009GL041635

> Jensen BB, Cox RP (1983) Direct measurements of steadystate kinetics of cyanobacterial $\mathrm{N}_{2}$ uptake by membraneleak mass spectrometry and comparisons between nitrogen fixation and acetylene reduction. Appl Environ Microbiol 45:1331-1337

Kérouel R, Aminot A (1997) Fluorometric determination of ammonia in sea and estuarine waters by direct segmented flow analysis. Mar Chem 57:265-275

Koçak M, Kubilay N, Tugrul S, Mihalopoulos N (2010) Longterm atmospheric nutrient inputs to the eastern Mediter- ranean: sources, solubility and comparison with riverine inputs. Biogeosciences Discuss 7:5081-5117

Kouvarakis G, Mihalopoulos N, Tselepides T, Stavrakakis S (2001) On the importance of atmospheric nitrogen inputs on the productivity of Eastern Mediterranean. Global Biogeochem Cycles 15:805-818

Krom MD, Kress N, Brenner S, Gordon LI (1991) Phosphorus limitation of primary productivity in the eastern Mediterranean Sea. Limnol Oceanogr 36:424-432

Krom MD, Herut B, Mantoura RFC (2004) Nutrient budget for the Eastern Mediterranean: implications for P limitation. Limnol Oceanogr 49:1582-1592

Kustka AB, Sañudo-Wilhemy SA, Carpenter EJ, Capone DG, Burns J, Sunda WG (2003) Iron requirements for dinitrogen- and ammonium-supported growth in cultures of field populations. Limnol Oceanogr 48:1869-1884

Langlois RJ, LaRoche J, Raab PA (2005) Diazotrophic diversity and distribution in the tropical and subtropical Atlantic Ocean. Appl Environ Microbiol 71:7910-7919

Le Moal M, Biegala IC (2009) Diazotrophic unicellular cyanobacteria in the northwestern Mediterranean Sea: a seasonal cycle. Limnol Oceanogr 54:845-855

Lund JWG, Kipling C, Lecren ED (1958) The inverted microscope method of estimating algal numbers and statistical basis of estimations by counting. Hydrobiol 11:143-170

Man-Aharonovich D, Kress N, Bar Zeev E, Berman-Frank I, Beja O (2007) Molecular ecology of nifH genes and transcripts in the Eastern Mediterranean Sea. Environ Microbiol 9:2354-2363

Margalef R (1969) Composición especifica del fitoplancton de la costa catalano-levantina (Mediterraneo occidental) en 1962-1967. Res Exp Cient B/o Cornide 2:65-94

Marino R, Howarth RW (1990) Molybdenum and sulfate as controls on the abundance of nitrogen-fixing cyanobacteria in saline lakes in Alberta. Limnol Oceanogr 35: $245-259$

- Markaki Z, Oikonomou K, Kocak M, Kouvarakis G, Chaniotaki A, Kubilay N, Mihalopoulos N (2003) Atmospheric deposition of inorganic phosphorus in the Levantine Basin, eastern Mediterranean: spatial, temporal variability and its role on the productivity of the eastern Mediterranean Sea. Limnol Oceanogr 48:1557-1568

Markaki Z, Loÿe-Pilot MD, Violaki K, Benyahya L, Mihalopoulos N (2008) Variability of atmospheric deposition of dissolved nitrogen and phosphorus in the Mediterranean and possible link to the anomalous seawater N/P ratio. Mar Chem 120:187-194

Mills MMC, Ridame M, Davey J, LaRoch R, Geider J (2004) Iron and phosphorus co-limit nitrogen fixation in the eastern tropical north Atlantic. Nature 429:292-294

- Montoya JP, Voss M, Kähler P, Capone D (1996) A simple, high precision, high-sensitivity tracer assay for $\mathrm{N}_{2}$ fixation. Appl Environ Microbiol 62:986-993

Moutin T, Raimbault P (2002) Primary production, carbon export and nutrients availability in western and eastern Mediterranean Sea in early summer 1996 (MINOS cruise). J Mar Syst 33-34:273-288

Mulholland MR (2007) The fate of nitrogen fixed by diazotrophs in the ocean. Biogeosciences 4:37-51

Mulholland MR, Bernhardt PW, Heil CA, Bronk DA, O'Neil JM (2006) Nitrogen fixation and regeneration in the Gulf of Mexico. Limnol Oceanogr 51:1762-1776

Pantoja S, Repeta DJ, Sachs JP, Sigman DM (2002) Stable isotope constraints on the nitrogen cycle of the Mediterranean Sea water column. Deep-Sea Res I 49:1609-1621

Parsons TR, Maita Y, Lalli CM (1984) A manual of chemical and biological methods for seawater analysis. Pergamon 
Press, New York, NY

Pekney NJ, Davidson CI (2005) Determination of trace elements in ambient aerosol samples. Anal Chim Acta 540: 269-277

Rees AP, Law CS, Woodward EMS (2006) High rates of nitrogen fixation during an in situ phosphate release experiment in the eastern Mediterranean Sea. Geophys Res Lett 33: L10607 doi: 101029/2006GL025791

Regaudie-de-Gioux A, Vaquer-Sunyer R, Duarte CM (2009) Patterns in planktonic metabolism in the Mediterranean Sea. Biogeosciences 6:3081-3089

Ribera d'Alcalà M, Civitarese G, Conversano F, Lavezza R (2003) Nutrient ratios and fluxes hint at overlooked processes in the Mediterranean Sea. J Geophys Res Ocean 108 doi:10.1029/2002jc001650

Ridame C, Moutin T, Guieu C (2003) Does phosphate adsorption onto Saharan dust explain the unusual N/P ratio in the Mediterranean Sea? Oceanol Acta 26:629-634

Ridame C, Le Moal M, Guieu C, Ternon E, Biegala IC, L'Helguen S, Pujo-Pay M (2011) Nutrient control of $\mathrm{N}_{2}$ fixation in the oligotrophic Mediterranean Sea and the impact of Saharan dust events. Biogeosciences Discuss 8:2629-2657

Saager PM, Schijf J, De Baar HJW (1993) Trace-metal distributions in seawater and anoxic brines in the eastern Mediterranean Sea. Geochim Cosmochim Acta 57:1419-1432

Sachs JP, Repeta DJ (1999) Oligotrophy and nitrogen fixation during eastern Mediterranean sapropel events. Science 286:2485-2488

Sandroni V, Raimbault P, Migon C, Garcia N, Gouze E (2007) Dry atmospheric deposition and diazotrophy as sources of new nitrogen to northwestern Mediterranean oligotrophic surface waters. Deep-Sea Res I 54:1859-1870

Sañudo-Wilhelmy SA, Kustka AB, Gobler CJ, Hutchins DA and others (2001) Phosphorous limitation on nitrogen fixation by Trichodesmium sp. in the central Atlantic Ocean. Nature 411:66-69

Sarthou G, Jeandel C (2001) Seasonal variations of iron

Editorial responsibility: Fereidoun Rassoulzadegan,

Villefranche-sur-Mer, France concentrations in the Ligurian Sea and iron budget in the western Mediterranean Sea. Mar Chem 74:115-129

Shapiro SS, Wilk MB (1965) An analysis of variance test for normality (complete samples). Biometrika 52:591-611

Sohm JA, Mahaffey C, Capone DG (2008) Assessment of relative phosphorus limitation of Trichodesmium spp. in the north Pacific, north Atlantic, and the north coast of Australia. Limnol Oceanogr 53:2495-2502

Stal L (1988) Nitrogen fixation in cyanobacterial mats. Methods Enzymol 167:474-481

Struck U, Emes K, Voß M, Krom MD, Rau GH (2001) Biological productivity during sapropel $\mathrm{S} 5$ formation in the eastern Mediterranean Sea: evidence from stable isotopes of nitrogen and carbon. Geochim Cosmochim Acta 65: 3249-3266

Tovar-Sánchez A, Sañudo-Wilhelmy SA (2011) Influence of the Amazon River on dissolved and intra-cellular metal concentrations in Trichodesmium colonies along the western boundary of the sub-tropical north Atlantic Ocean. Biogeosciences 8:217-225

Tyrrell T, Marañon E, Poulton AJ, Bowie AR, Harbour DS, Malcolm A, Woodward S (2003) Large-scale latitudinal distribution of Trichodesmium spp. in the Atlantic Ocean. J Plankton Res 25:405-416

Venrick EL (1974) The distribution and significance of Richelia intracellularis Schmidt in the north Pacific Central Gyre. Limnol Oceanogr 19:437-445

Wagener T, Pulido-Villena E, Guieu C (2008) Dust iron dissolution in seawater: results from a one-year time-series in the Mediterranean Sea. Geophys Res Lett 35:L16601 doi:10.1029/2008GL034581

Wimpenny RS (1966) The size of diatoms. IV. The cell diameters in Rhizosolenia styliformis var. oceanica. J Mar Biol Assoc UK 46:541-546

Yogev T, Rahav E, Bar-Zeev E, Man-Aharonovich D and others (2011) Is dinitrogen fixation significant in the Levantine Basin, east Mediterranean Sea? Environ Microbiol (in press) doi:10.1111/j.1462-2920.2010.02402.x

Submitted: December 20, 2010; Accepted: April 8, 2011

Proofs received from author(s): July 11, 2011 